3R 小型マニピュレータの開発と制御

\title{
A Study on Development and Control of 3 Rotation type Robot Manipulator
}

○蔡 泓㑭（信州大） 正 河村 隆（信州大）

Hongyi CAI, Shinshu University, Japan

Takashi KAWAMURA, Shinshu University, Japan

Key words: Micromachine, Rotating axis, Pulse feedback, Vector analysis

\section{1. 研究背景}

現在，産業界においては，生産の拠点が国外へ移行する 中, 国内においては技術の空洞化現象が顕著に現れてきて おります。とりわ電子機器産業である第二次産業分野で は，機器のダウンサイジング（軽薄短小現象）が更に押し 進められ, 携帯電話, パソコン, 電子手帳, GPS, ディス プレイ, 半導体素子と言った情報機器, 各種表示機器, 半 導体素子部品自体が小型, 多機能化, そして低コスト化を 実現されてきております。また，医療機器，生命体分野に 目を向けた場合，昨今のバイオテクノロジに見られる様に， 精細化, 高精度化に必要な「マイクロマシン技術」が，今 後，拡大的に要求されてくるものと推測しております。

\section{2. 用途と分野}

本研究の用途は「コンピュータでコントローラーを用い て, 先端にピンセットやはさみを取り付けて, マイクロ移 動とカットを基本とする一連のマイクロ部品操作をスム 一ズに行うッール」と考える.また, 以下の記載する分野 の応用が考えされる。

\section{i. 半導体関連市場}

電子デバイス開発分野において，ベアチップ製法手段と してのマイクロマシーンツールとして適応できる。例えば， クリーンルーム内にて顥微鏡を預きながら，マイクロチッ プデバイスの結合, ハンドリング, 移動, カット, 剥離な どの操作作業に使用できる。

ii. 大学や公的機関の研究所における研究開発分野 各種大学研究室, 公的機関 (工業試験場, 工業技術院な ど）の研究所において開発，研究する上で，特に「マイク 口作業分野」への作業ツールとして適応可能である. 例え ば, ピンセットやッーリング（ロッド棒など）をマニプレ 一ターに搭載しての各種ツール作業, マイクロ加工作業な どに適応できる。

\section{3. 改良実験装置構造}

基本構造：「曲げ」「ひねり」「振り」3R 回転軸 (Fig. 1) 駆動方式: 駆動源は DCサーボアクチュエータ

(ハーモニックドライバシステムズ株式会社製 RH-5A)

可動範囲：振り軸 $+/-180^{\circ}$ 以上

$$
\text { 曲げ軸 }+/-180^{\circ} \text { 以上 }
$$$$
\text { ひねり軸 }+/-180^{\circ} \text { 以上 }
$$

Fig. 1 の基準姿勢で, 最大長さ：148 m m

最大高さ：163m m

最大幅 : $135 \mathrm{~m} \mathrm{~m}$

先端に液圧動作のピンセットを取り付ける。ベースに手動
ステージ（ $\mathrm{x}$ 軸と $\mathrm{y}$ 軸方向の移動できる）を付ける.

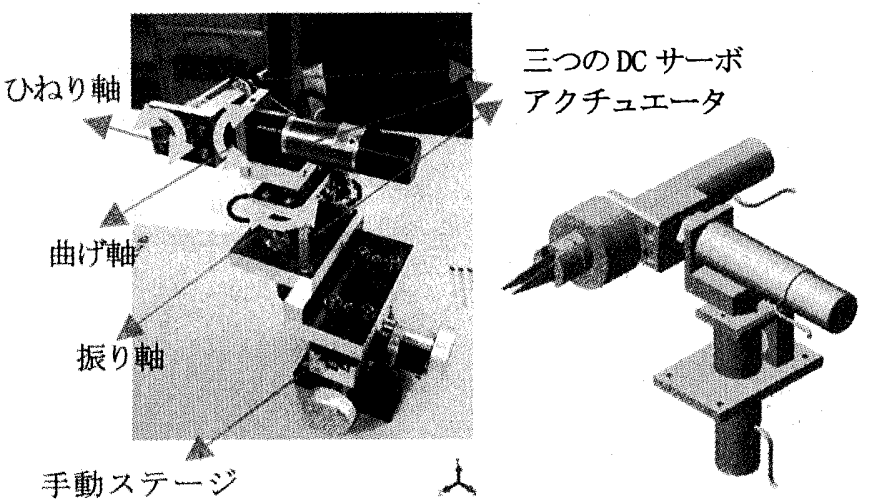

Fig. 1 実験装置基本仕様略図

4. 実験システム構成

次は理論的に実験原理を論述して行う.DCサーボモータ データ通信制御プロセス図はFig. 2 に示す.

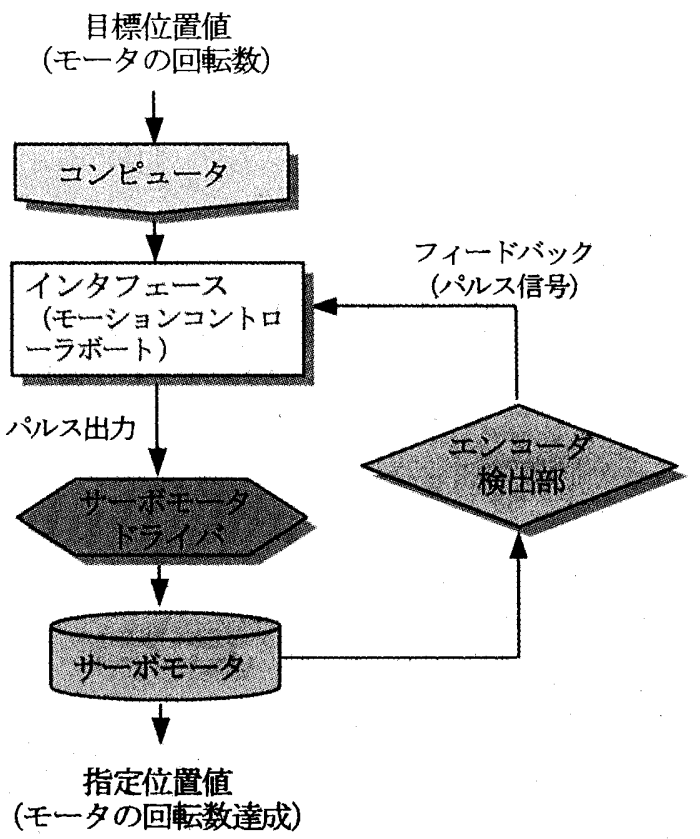

Fig. 2 モータのデータ通信制御系構成

Fig. 3. は DC サーボモータとモータドライバ及びインタ フェースボード (インタフェース株式会社製モーションコ ントローラボードPCI-7404V) の接続図を示す. 


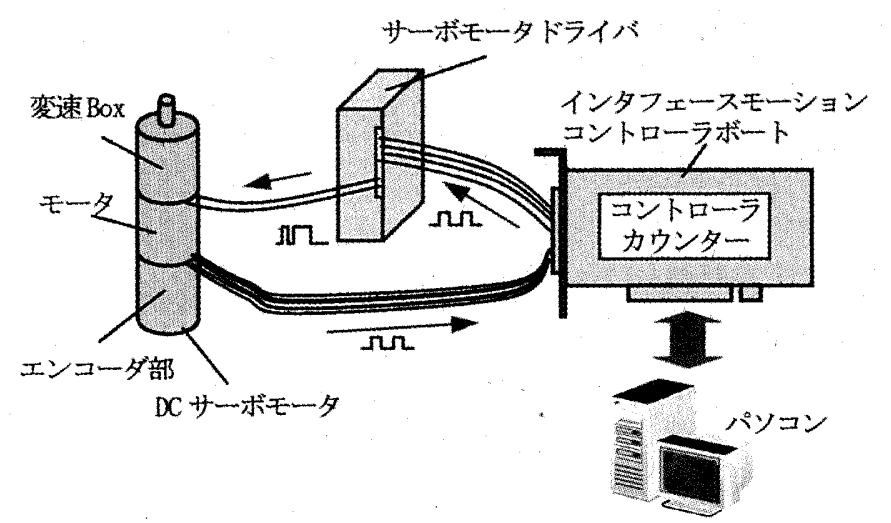

Fig. 3 実験装置のシステムの構成

実験のプロセス原理 : 目標位置値入力, モータの軸の回 転数 $\times$ 分解能 $(360 \mathrm{p} / \mathrm{r}) \times$ 減速比 $(100)$ の值をインタ 一フェイスボートに入力して, カウントする. 次はインタ 一フェイスボートから出力されるパルス数をモータドラ イバに入力して（パルス方式入力モータドライバ, サーボ テクノ株式会社製 PMC112A），モータの位膡決め及び速度 制御ができる。

サーボモータのフィードバック：モータのエンコーダ部 から出力されるパルスをインターフェイスボートにフィ 一ドバックして，カウントする.

5. マニピュレータの運動学解析モデル

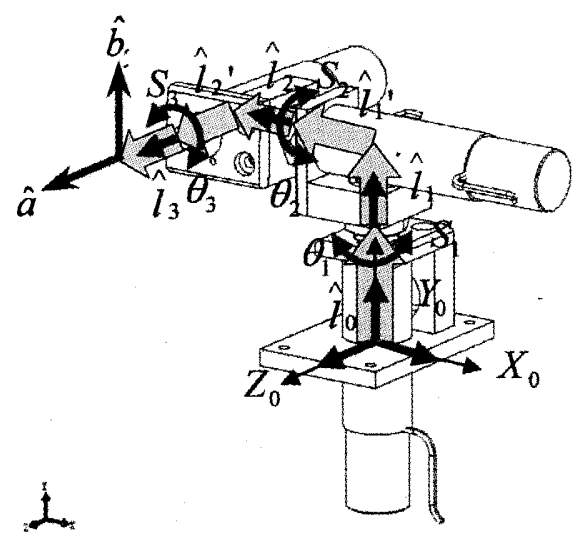

Fig. 4 基凖姿勢におけるべクトル解析図

\section{マニピュレータの先端のベクトル解析}

（1）マニピュレータの基準姿勢をFig.4のように設定し

(2) マニピュレータの先端のベクトル方程式は以下のよ うに求まる。

$$
\begin{aligned}
P_{r} & =\hat{l}_{0}+R_{1}\left(\hat{l}_{1}+\hat{l}_{1}^{\prime}+R_{2}\left(\hat{l}_{2}+\hat{l}_{2}^{\prime}+R_{3}\left(\hat{l}_{3}\right)\right)\right) \\
& =L_{0}+L_{1}+L_{2}+L_{3} \\
& =\left[\begin{array}{l}
0 \\
l_{0} \\
0
\end{array}\right]+\left[\begin{array}{c}
-C_{1} l_{1}^{\prime} \\
l_{1} \\
-S_{1} l_{1}^{\prime}
\end{array}\right]+\left[\begin{array}{c}
-C_{1} l_{2}+S_{1} C_{2} l_{2} \\
-S_{2} l_{2} \\
-S_{1} l_{2}+C_{1} C_{2} l_{2}
\end{array}\right]+\left[\begin{array}{c}
S_{1} C_{2} l_{3} \\
-S_{2} l_{3} \\
C_{1} C_{2} l_{3}
\end{array}\right] \\
& =\left[\begin{array}{c}
C_{1}\left(l_{2}-l_{1}^{\prime}\right)+S_{1} C_{2}\left(l_{2}+l_{3}\right) \\
l_{0}+l_{1}-S_{2}\left(l_{2}+l_{3}\right) \\
S_{1}\left(l_{2}-l_{1}^{\prime}\right)+C_{1} C_{2}\left(l_{2}+l_{3}\right)
\end{array}\right]
\end{aligned}
$$

先端ベクトル式よって，

$$
\left\{\begin{array}{l}
P x=C_{1}\left(l_{2}-l_{1}{ }^{\prime}\right)+S_{1} C_{2}\left(l_{2}+l_{3}\right) \\
P y=l_{0}+l_{1}-S_{2}\left(l_{2}+l_{3}\right) \\
P z=S_{1}\left(l_{2}-l_{1}{ }^{\prime}\right)+C_{1} C_{2}\left(l_{2}+l_{3}\right)
\end{array}\right.
$$

逆運動学で, 以上三つ式の逆解から関節の回転角度 $\theta_{1}$ $\theta_{2} \theta_{3}$ を求めることができる.

\section{6. 実験プロセスのイメージ}

3R 小型マニピュレータの定速起動で目標位置制御のイ メージを Fig. 5 示す. 対象物は $3 \mathrm{~mm}$ の立方体 (カ公製). 目標 軌道は台の一段目位置(1)から二段目の位置(2)まで.
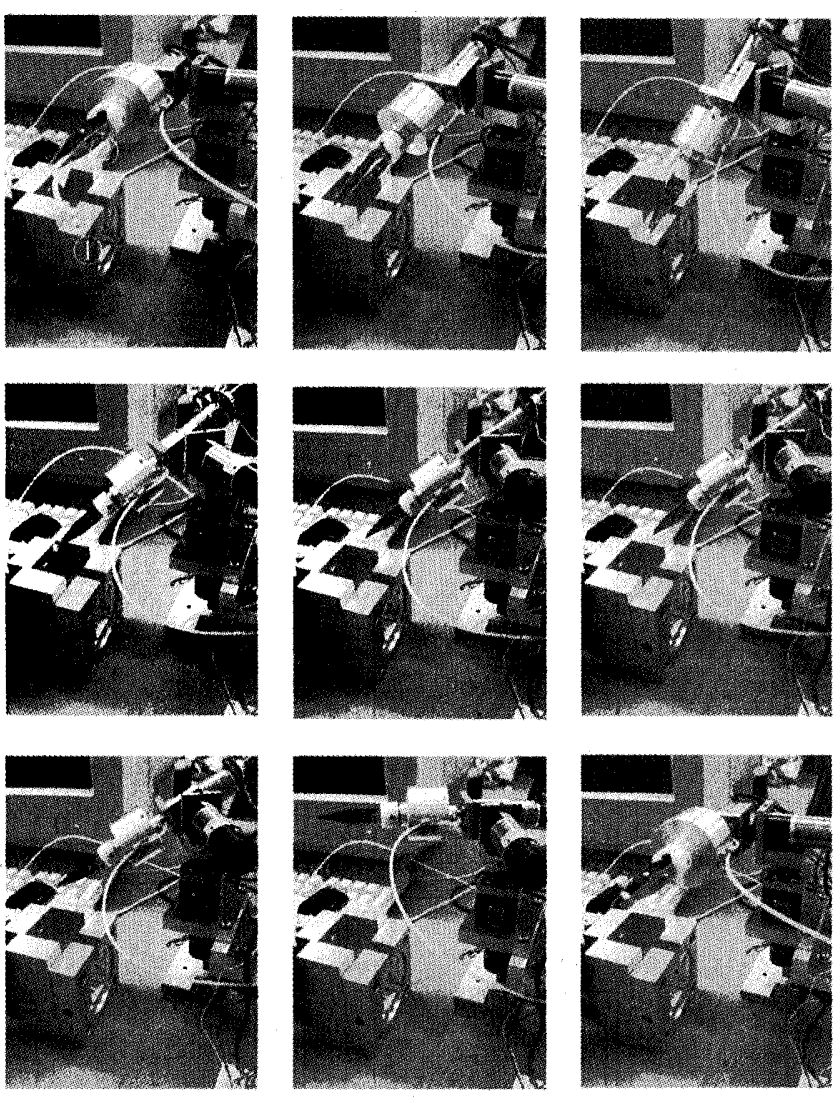

Fig. 5 目標軌道制御イメージ

\section{7. 結言}

現在まで $3 \mathrm{R}$ 小型マニピュレータの試作を完成した。ま た, マニピュレータの運動学モデルを解析できた. 回転軸 定速起動動作制御の目標值々実験結果の比較を確認でき た。また，一応の軌道制御を確認できた．今後，更に変速 起動の奏現及び軌道制御の精度を高めていく必要がある.

\section{参考文献}

[1] 広瀬茂男 : ロボット工学 (改訂版), 東京裳華堂 (1987),

[2] 有本卓 : ロボットの力学と制御, 朝倉書店 (1990) 